\title{
In Retrospect: Calvino's Cosmicomics
}

\section{The soaring imagination of the Italian author abounds in a new compilation of his cosmic fables. Mostly written in the age of the space race, they are heavily informed by science, finds Alan Lightman.}

In one of the stories in Italo Calvino's The Complete Cosmicomics, the inimitable character named Qfwfq is gambling with Dean $(\mathrm{k})$ $\mathrm{yK}$ in the nothingness before time and space began. "I don't want to boast," announces Qfwfq, "but from the start I was willing to bet there was going to be a universe, and I hit the nail on the head ... We were always gambling, the Dean and I, because there was really nothing else to do, and also because the only proof I existed was that I bet with him, and the only proof he existed was that he bet with me."

Wildly inventive, philosophical and playful at once, addicted to sustained metaphors, Calvino is almost unique in his fictions. One might compare him to José Saramago or Jorge Luis Borges, but few others. In Calvino's dazzling Invisible Cities, the explorer Marco Polo reports to Genghis Khan about each of the marvellous cities in the Khan's empire, the descriptions exquisite in their crystalline prose. In The Baron in the Trees, a man lives among the leaves and branches of trees, viewing the world from far above the ground.

The Complete Cosmicomics combines several earlier works: Cosmicomics (1968) and Time and the Hunter (1969), both translated by William Weaver; four stories from Numbers in the Dark (1995), translated by Tim Parks; and seven tales from World Memory and Other Cosmicomic Stories (1968), newly translated by Martin McLaughlin.

Most of these stories were written between 1963 and 1968, in the heat of the space race between the United States and the Soviet Union. They are heavily informed by science, especially astronomy and cosmology but also evolution and cell biology. In one of the yarns, for exam-

ple, the protagonist is an ageing dinosaur who has somehow survived the extinction of his species and hides out, like a

\section{The Complete Cosmicomics}

by Italo Calvino

Translated by William Weaver, Tim Parks and Martin McLaughlin

Penguin Classics: 2009. 304 pp. $€ 20$

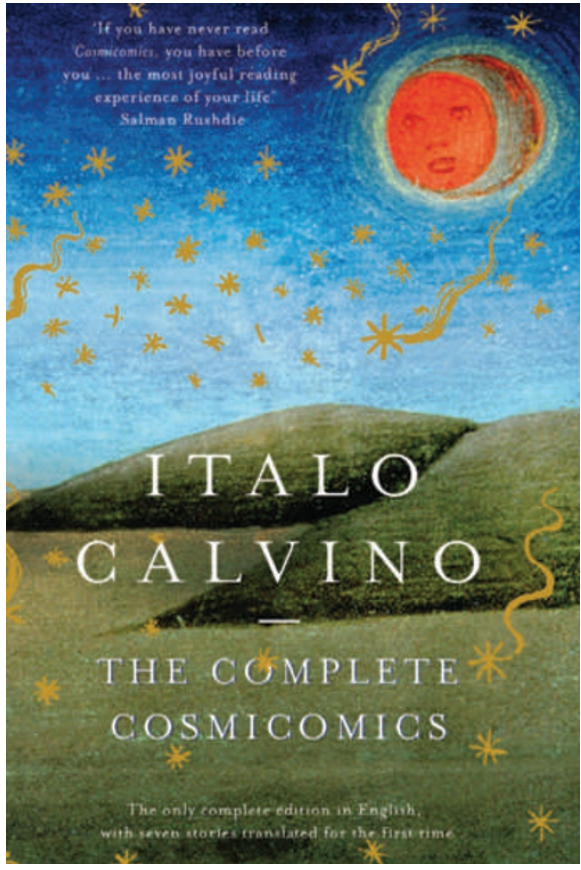

Colloquialisms nestle happily with scientific terminology in Calvino's playful approach.

with the other man, a moustachioed lieutenant. In another, the main character is a mollusc: "I try to persuade myself that the two holes I had were a mouth and an anus ... Every now and then, I was seized by fantasies, that's true, for example, the notion of scratching my armpit, or crossing my legs, or once even growing a moustache."

Many of the stories concern cosmic beings who offer witty commentary on the formation of the Universe and have the wondrous capacity to casually wander across time and space. They exist in the cushiony folds of cosmic nebulae, or in empty space, or falling in the gravitational pull of war criminal, in a tribe of descendant reptilians called 'New Ones'. The interloper is, by turns, embarrassed, secretive, defensive and finally indignant about his origins, falling in love and then being rejected by one of the new females. In another tale, two men and a woman fall through empty space for untold centuries, the narrator attempting to steer his trajectory closer to the woman and imagining a rivalry distant galaxies. Calvino makes no attempt to be logically consistent or scientifically plausible, and herein arises much of the humour and charm of the book. Molluscs imagine armpits, cold exists before the Universe existed, people climb ladders and jump on to the Moon.

In 'At Daybreak' a squabbling family stumbles across "pinnacles, spires, and battlements" of condensing gas in a new-formed nebula. In
'As Long as the Sun Lasts', Qfwfq's grandparents trade insults about which stars to set up camp near: "And why not the other one? The bigger they are, the more I trust them." "Are you mad, don't you know what that is? Don't you know about the blue ones? They burn so fast, you don't even notice, and barely a couple of thousand millennia go by and you've already got to start packing." Colloquialisms nestle happily with scientific terminology.

We never know who these cosmic supermen are, where they came from, or how they got to be where they are. In Cosmicomics, there are no houses and chairs, no roads or cars, no banks or telephones, no Berlin or London. There is no human civilization at all. Yet we do meet intelligent beings, even families and lovers, attempting to make sense of life in its most elemental form. It seems that Calvino is attempting to fathom how much of a reality can be created without familiar geography of time and space. He plays with science the way a found-object artist throws together bits of silvered glass, odd metal brackets, bits of coloured paper.

It is impossible not to compare Calvino to another of his Italian countrymen, Primo Levi. Both wrote imaginative fiction inspired by science. Calvino's Complete Cosmicomics is more fanciful and playful than Levi's Periodic Table. Levi's characters in the latter are far richer. The most interesting of Calvino's fables, in my opinion, are the ones with human drama. The least interesting are those in which the author goes into long pedagogical riffs on science or indulges in pages of philosophical reflection. When Calvino brings together human drama with his imaginative scenarios, and philosophy with his beautiful language, humour and wit, he is unparallelled.

In the story titled 'World Memory', an organization is entrusted with the job of storing all of the world's knowledge and culture in the face of an impending cataclysm. "The duty of the director is to make sure that nothing is left out, because what is left out is as if it had never been." Fortunately for future generations of world civilization, Calvino has been, and he will certainly not be left out.

Alan Lightman is a physicist, writer and adjunct professor of humanities at the Massachusetts Institute of Technology, Cambridge,

Massachusetts 02139, USA. His forthcoming book, the narrative poem Song of Two Worlds, will be published in October 2009. 